\title{
EFFECT OF SPRAYING SILICON AND SELENIUM ON GROWTH, VINE NUTRITIONAL STATUS, BERRY SETTING, YIELD AND BERRIES QUALITY OF SUPERIOR GRAPEVINES GROWN UNDER SANDY SOIL CONDITIONS
}

\author{
II-THE EFFECT ON BERRY SETTING, YIELD AND BERRIES \\ QUALITY \\ Ahmed, M.M.A. Akl"; Faissal F. Ahmed"; Mohamed A.M. Abada ${ }^{* * *}$ and \\ Sameh, E.M. Yassen ${ }^{* *}$ \\ "Hort. Dept., Fac. of Agric., Minia Univ., Egypt. \\ **Viticulture Res. Dept., Hort. Res. Instit. ARC, Giza, Egypt \\ E mail: faissalfadel@yahoo.com
}

\begin{abstract}
This study was carried out during 2014 and 2015 seasons to examine the effect of spraying potassium silicate at 0.125 to $0.5 \%$ and/or selenium at 50 to $200 \mathrm{ppm}$ on yield and berries quality of Superior grapevines grown in sandy soil.

Berry setting, yield and both physical and chemical parameters of quality were remarkably improved due to using potassium silicate at 0.125 to $0.5 \%$ and/or selenium at 50 to $200 \mathrm{ppm}$ compared to the control treatment. No considerable effect was observed on the investigated characteristics due to increasing potassium silicate concentrations from 0.25 to $0.5 \%$ and selenium from 100 to $200 \mathrm{ppm}$.

The best results with regard to yield and berries quality of Superior grapevines grown under sandy soil conditions were observed due to treating the vines three times with a mixture of potassium silicate at $0.25 \%$ and selenium at $100 \mathrm{ppm}$.
\end{abstract}

Keywords: Silicon, Selenium, Superior grapevines, berry setting, yield and berries quality.

\section{INTRODUCTION}

The beneficial effects of silicon and selenium on growth and vine nutritional status surely reflected on improving berry setting, yield and berries quality in different grapevine cvs.

Silicon is responsible for enhancing growth and salinity and drought tolerance, water retention, photosynthesis, root development and different disorders (Rodrigues $\boldsymbol{e t}$ al., 2003; Melo et al., 2003; Lux et al., 2003; Ma, 2004 and Tahir, et al., 2006).

Selenium was found by many authors to enhance the activities of enzymes such as glutathione peroxidase, the tolerance of vines to abiotic and biotic stresses

Fayoum J. Agric. Res. \& Dev., Vol. 31, No.2, July, 2017 
Ahmed, M.M.A. Akl; ; et al.,

and the biosynthesis of carbohydrates and proteins. It also reduces reactive oxygen species (ROS) and protects plant cells from aging and death (Seppanen $\boldsymbol{e t}$ al., 2003; Nowak-Barbara, 2008 and Jakovljevic et al., 2011).

Previous studies showed that silicon (Abd El-Hameed, 2012; Ibrahiem and Al-Wasfy, 2014; El-Khawaga, 2014; Wassel et al., 2015; Nagy-Dina, 2016; Akl et al., 2016, Farahat, 2017 and Youssef, 2017) and selenium (AlWasfy, 2014; Gad El-Kareem et al., 2014 and Uwakiem, 2015) had an announced promotion on berry setting, yield and berries quality grown under unsuitable environmental conditions.

The target of this study was examining the effect of single and combined applications of silicon and selenium on berry setting, yield and berries quality of Superior grapevines grown in sandy soil.

\section{MATERIALS AND METHODS}

This study ( $2^{\text {nd }}$ part) was carried out during 2014 and 2015 seasons on sixty uniform in vigour 8-years old Superior grapevines. The selected vines are grown in a private vineyard located at Gerga district, Souhag Governorate where the texture of the soil is Sandy (Table 1). Soil analysis was done according to the procedures that outlined by Piper (1950) and Black. (1965).

The selected vines are planted at 2 × 3 meters apart (700 vines/fed.). The chosen vines were trained by cane pruning system leaving 72 eyes/ vine (six fruiting canes x 10 eyes plus six renewal spurs / two eyes) using Gable supporting method. Winter pruning was carried out at the first week of Jan. during both seasons. Drip irrigation system was followed using well water containing 500 ppm salinity.

Table (1): Analysis of the tested soil

\begin{tabular}{|c|c|}
\hline Constituent & Values \\
\hline Sand \% & 76.2 \\
\hline Silt \% & 12.1 \\
\hline Clay \% & 11.7 \\
\hline Texture & Sandy \\
\hline O.M. \% & 0.11 \\
\hline $\mathrm{pH}(1: 2.5$ extract $)$ & 7.69 \\
\hline $\mathrm{EC}(1: 2.5$ extract $)\left(\mathrm{mmhhos} / \mathrm{cm} / 25^{\circ} \mathrm{C}\right)$ & 1.01 \\
\hline $\mathrm{CaCO}_{3} \%$ & 3.00 \\
\hline Total $\%$ & 0.005 \\
\hline Available P $($ Olsen method, $\mathrm{ppm})$ & 1.1 \\
\hline Available $\mathrm{K}($ ammonium acetate, $\mathrm{ppm})$ & 31.0 \\
\hline
\end{tabular}

Fayoum J. Agric. Res. \& Dev., Vol. 31, No.2, July, 2017 
EFFECT OF SPRAYING SILICON AND SELENIUM ON GROWTH,...... 147 Common horticultural practices such as fertilization, twice hoeings, irrigation, pinching and pest management were carried out as usual.

This study consisted from the following ten treatments:

1- Control vines (sprayed with water).

2- Spraying potassium silicate at $0.125 \%(1.25 \mathrm{~g} / \mathrm{l})$.

3- Spraying potassium silicate at $0.25 \%(2.5 \mathrm{~g} / \mathrm{l})$.

4- Spraying potassium silicate at $0.5 \%(5.0 \mathrm{~g} / \mathrm{l})$.

5- Spraying selenium at $50 \mathrm{ppm}(50 \mathrm{~g} / \mathrm{l})$.

6- Spraying selenium at $100 \mathrm{ppm}(100 \mathrm{mg} / \mathrm{l})$.

7- Spraying selenium at $200 \mathrm{ppm}(200 \mathrm{mg} / \mathrm{l})$.

8- Spraying potassium-silicate at $0.125 \%+$ selenium at $50 \mathrm{ppm}$.

9- Spraying potassium-silicate at $0.25 \%+$ selenium at $100 \mathrm{ppm}$.

10- Spraying potassium-silicate at $0.5 \%+$ selenium at $200 \mathrm{ppm}$.

Each treatment was replicated three times, two vines per each. Both potassium silicate $(25 \% \mathrm{Si}$ and $10 \% \mathrm{~K})$ and selenium $(100 \% \mathrm{Se})$ were sprayed three times at growth start ( $1^{\text {st }}$ week of Mar.), just after berry setting (last week of April) and three weeks later ( $3^{\text {rd }}$ week of May). Triton B as a wetting agent was added to all spraying solutions at $0.05 \%$. Spraying was done till runoff $(1.2 \mathrm{~L} /$ vine according to the date of spraying).

Randomized complete block design (RCBD) was adopted for carrying out statistical analysis of this study.

During both seasons, the following measurements were recorded:

1. Percentage of berry setting, yield/vine (kg.), number of clusters as well as weight (g.), length and shoulder of clusters $(\mathrm{cm})$

2. Physical and chemical characteristics of the berries namely berry weight (g.), longitudinal and equatorial (cm.), T.S.S.\%, total sugars\% and total acidity\% (as g tartaric acid/100 ml juice) (A.O.A.C, 2000).

Statistical analysis was done. Treatment means were compared using new L.S.D. at 5\% (Mead et al., 1993).

\section{RESULTS AND DISCUSSION}

\section{1- Percentage of berry setting, yield and cluster aspects:}

It is evident from the obtained data in Table (2) that treating Superior grapevines three times with silicon and/or selenium significantly improved the percentage of berry setting, yield expressed in weight and number of clusters/vine as well as weight, length and shoulder of cluster relative to the check treatment. There was a gradual promotion on these parameters with increasing concentrations of potassium silicate and selenium. Increasing concentrations of potassium silicate from 0.25 to $0.50 \%$ had no significant promotion on the percentage of berry setting, yield, number of clusters/vine, weight, length and

Fayoum J. Agric. Res. \& Dev., Vol. 31, No.2, July, 2017 
Ahmed, M.M.A. Akl; ; et al., shoulder of cluster. Application of silicon was significantly preferable in improving these measurements than using selenium. Combined applications significantly were accompanied with improving these parameter relative to using each material alone. From economical point of view, the best results with regard to berry setting, yield and cluster aspects were obtained due to treating the vines three times with a medium concentration of silicon $(0.25 \%)$ and selenium $(100 \mathrm{ppm})$. Under such promised treatment, yield per vine reached 10.2 and $14.4 \mathrm{~kg}$ during both seasons, respectively. The untreated vines produced yield per vine reached 8.2 and $7.8 \mathrm{~kg}$ during both seasons, respectively. The percentage of increment of the yield/vine in the promised treatment over the control treatment reached 24.4 and $84.6 \%$ during both seasons, respectively. Similar trend was noticed during both seasons. Number of clusters/vine in the first seasons was unsignificantly affected.

\section{2- Percentage of shot berries:}

It is revealed from the obtained data in Table (2) that single and combined applications of silicon and selenium significantly reduced the percentage of shot berries relative to the control treatment. The reduction was clearly associated with increasing concentrations of silicon and selenium. Using silicon was significantly superior to using selenium in reducing such undesirable phenomenon. Combined applications of silicon and selenium was significantly favorable than using each one alone in controlling shot berries. The lowest values of shot berries ( $4.5 \& 4.4 \%)$ were recorded on the cluster harvested from vines received three sprays of a mixture of potassium silicate at $0.5 \%$ plus selenium at $200 \mathrm{ppm}$. The highest values of shot berries $(12.7 \& 12.5 \%)$ were recorded on the clusters of the vines that untreated with silicon and selenium. Similar trend was noticed during both seasons.

Table (2): Effect of single and combined applications of silicon and selenium on the percentage of berry setting, yield, cluster aspects and percentages of shot berries of Superior grapevines during 2014 and 2015 seasons.

\begin{tabular}{|c|c|c|c|c|c|c|c|c|c|c|c|c|c|c|}
\hline \multirow[t]{2}{*}{ Treatments } & \multicolumn{2}{|c|}{$\begin{array}{c}\text { Berry setting } \\
\%\end{array}$} & \multicolumn{2}{|c|}{\begin{tabular}{|c|}
$\begin{array}{c}\text { No. of clusters } \\
\text { /vine }\end{array}$ \\
\end{tabular}} & \multicolumn{2}{|c|}{ Yield/vine (kg) } & \multicolumn{2}{|c|}{$\begin{array}{l}\text { Cluster weight } \\
\text { (g) }\end{array}$} & \multicolumn{2}{|c|}{$\begin{array}{c}\text { Cluster length } \\
(\mathrm{cm})\end{array}$} & \multicolumn{2}{|c|}{\begin{tabular}{|c|} 
Cluster \\
shoulder $(\mathrm{cm})$
\end{tabular}} & \multicolumn{2}{|c|}{$\begin{array}{c}\text { Shot berries } \\
\%\end{array}$} \\
\hline & 2014 & 2015 & 2014 & 2015 & 2014 & 2015 & 2014 & 2015 & 2014 & 2015 & 2014 & 2015 & 2014 & 2015 \\
\hline Control & 11.1 & 10.8 & 24.0 & 23.0 & 8.2 & 7.8 & 340.0 & 341.0 & 17.5 & 17.7 & 12.7 & 12.5 & 11.5 & 11.6 \\
\hline K-Silicate at $0.125 \%$ & 14.7 & 15.0 & 24.0 & 29.0 & 9.0 & 10.9 & 375.0 & 376.5 & 19.0 & 19.2 & 13.1 & 12.9 & 8.0 & 7.9 \\
\hline K-Silicate at $0.250 \%$ & 15.8 & 16.0 & 24.0 & 31.0 & 9.3 & 12.0 & 386.0 & .0 & 19.5 & .8 & 13.6 & 3.4 & 7.0 & 6.8 \\
\hline K-Silicate at $0.5 \%$ & 16.0 & 16.1 & 24.0 & 31.0 & 9.3 & 12.0 & 387.0 & 387.0 & 19.6 & 19.9 & 13.7 & 13.5 & 6.9 & 6.7 \\
\hline Selenium (Se) at $50 \mathrm{ppm}$ & 12.3 & 12.5 & 24.0 & 25.0 & 8.4 & 8.8 & 351.0 & 352.5 & 18.0 & 18.0 & 12.1 & 11.9 & 10.9 & 10.8 \\
\hline Selenium at $100 \mathrm{ppm}$ & 13.4 & 13.6 & 25.0 & 27.0 & 9.1 & 9.8 & 362.0 & 363.0 & 18.4 & 18.5 & 12.5 & 12.3 & 9.8 & 9.7 \\
\hline Selenium at $200 \mathrm{ppm}$ & 13.5 & 13.7 & 25.0 & 27.0 & 9.1 & 9.8 & 363.0 & 363.3 & 18.5 & 18.6 & 12.6 & 12.4 & 9.4 & 9.3 \\
\hline $\begin{array}{l}\text { K-Silicate at } 0.125 \%+ \\
\text { Se at } 50 \mathrm{ppm}\end{array}$ & 17.1 & 17.3 & 25.0 & 33.0 & 10.0 & 13.2 & 398.0 & 400.0 & 20.2 & 20.3 & 14.2 & 14.0 & 5.2 & 5.0 \\
\hline $\begin{array}{c}\text { K-Silicate at } 0.25 \%+ \\
\text { Se at } 100 \mathrm{ppm}\end{array}$ & 18.3 & 18.6 & 25.0 & 35.0 & 10.2 & 14.4 & 409.0 & 410.0 & 20.7 & 20.8 & 14.6 & 14.4 & 4.6 & 4.5 \\
\hline $\begin{array}{c}\text { K-Silicate at } 0.5 \%+ \\
\text { Se at } 200 \mathrm{ppm} \\
\end{array}$ & 18.4 & 18.7 & 25.0 & 35.0 & 10.2 & 14.4 & 409.0 & 410.9 & 20.8 & 20.9 & 14.7 & 14.5 & 4.5 & 4.4 \\
\hline New L.S.D. at 5\% & 1.0 & 0.9 & NS & 2.0 & 0.7 & 1.0 & 10.0 & 9.9 & 0.4 & 0.3 & 0.4 & 0.3 & 0.4 & 0.3 \\
\hline
\end{tabular}

Fayoum J. Agric. Res. \& Dev., Vol. 31, No.2, July, 2017 
EFFECT OF SPRAYING SILICON AND SELENIUM ON GROWTH

\section{3- Physical and chemical characteristics of the berries:}

Data in the Table (3) clearly show that supplying the vines with silicon and/or selenium significantly was responsible for improving quality of the berries in terms of increasing berry weight, longitudinal and equatorial, T.S.S.\% and total sugars $\%$ and reducing total acidity $\%$ relative to the control treatment. The promotion on both physical and chemical characteristics was related to the increase in concentrations of silicon and selenium. Negligible promotion on quality of the berries was observed among the higher two concentrations of both silicon and selenium. Using silicon was significantly preferable than using selenium in this connection. Combined applications were significantly superior than using each material alone in this respect. From economical point of view, the best results with regard to quality of the berries were recorded on the vines that received three sprays of a mixture of potassium silicate at $0.5 \%$ and selenium at $200 \mathrm{ppm}$. Low fruit quality indices were observed on untreated vine. These results were true during both seasons.

Table (3): Effect of single and combined applications of silicon and selenium on some physical and chemical characteristics of the berries of Superior grapevines during 2014 and 2015 seasons.

\begin{tabular}{|c|c|c|c|c|c|c|c|c|c|c|c|c|}
\hline \multirow{2}{*}{ Treatments } & \multicolumn{2}{|c|}{ Berry weight (g) } & \multicolumn{2}{|c|}{\begin{tabular}{|c|} 
Berry \\
longitudinal $(\mathrm{cm})$
\end{tabular}} & \multicolumn{2}{|c|}{$\begin{array}{c}\text { Berry equatorial } \\
(\mathbf{c m})\end{array}$} & \multicolumn{2}{|c|}{ T.S.S.\% } & \multicolumn{2}{|c|}{$\begin{array}{c}\text { Reducing sugars } \\
\%\end{array}$} & \multicolumn{2}{|c|}{$\begin{array}{c}\text { Total acidity } \\
\%\end{array}$} \\
\hline & 2014 & 2015 & 2014 & 2015 & 2014 & 2015 & 2014 & 2015 & 2014 & 2015 & 2014 & 2015 \\
\hline Control & 2.74 & 2.77 & 2.11 & 2.14 & 1.91 & 1.95 & 17.7 & 17.1 & 15.1 & 15.2 & 0.709 & 0.707 \\
\hline K-Silicate at $0.125 \%$ & 3.03 & 3.07 & 2.32 & 2.31 & 2.07 & 2.12 & 19.3 & 18.5 & 16.5 & 16.6 & 0.629 & 0.630 \\
\hline K-Silicate at $0.250 \%$ & 3.13 & 3.16 & 2.41 & 2.36 & 2.14 & 2.17 & 19.8 & 19.3 & 17.0 & 17.1 & 0.605 & 0.610 \\
\hline K-Silicate at $0.5 \%$ & 3.14 & 3.18 & 2.42 & 2.37 & 2.15 & 2.18 & 19.9 & 19.4 & 17.1 & 17.2 & 0.603 & 0.609 \\
\hline Selenium (Se) at $50 \mathrm{ppm}$ & 2.82 & 2.86 & 2.17 & 2.19 & 1.96 & 1.99 & 18.2 & 17.6 & 15.5 & 15.5 & 0.680 & 0.680 \\
\hline Selenium at $100 \mathrm{ppm}$ & 2.91 & 2.96 & 2.25 & 2.25 & 2.01 & 2.05 & 18.7 & 18.0 & 16.0 & 16.0 & 0.651 & 0.660 \\
\hline Selenium at $200 \mathrm{ppm}$ & 2.93 & 2.98 & 2.27 & 2.26 & 2.02 & 2.06 & 18.8 & 18.1 & 16.1 & 16.1 & 0.649 & 0.659 \\
\hline $\begin{array}{c}\text { K-Silicate at } 0.125 \%+ \\
\text { Se at } 50 \mathrm{ppm}\end{array}$ & 3.22 & 3.28 & 2.49 & 2.43 & 2.20 & 2.24 & 20.4 & 20.0 & 17.5 & 17.7 & 0.581 & 0.585 \\
\hline $\begin{array}{c}\text { K-Silicate at } 0.25 \%+ \\
\text { Se at } 100 \mathrm{ppm}\end{array}$ & 3.31 & 3.33 & 2.56 & 2.50 & 2.25 & 2.30 & 20.8 & 20.5 & 18.0 & 18.2 & 0.561 & 0.565 \\
\hline $\begin{array}{c}\text { K-Silicate at } 0.5 \%+ \\
\text { Se at } 200 \mathrm{ppm}\end{array}$ & 3.32 & 3.34 & 2.57 & 2.51 & 2.26 & 2.31 & 20.9 & 20.6 & 18.1 & 18.3 & 0.559 & 0.564 \\
\hline New L.S.D. at 5\% & 0.06 & 0.05 & 0.05 & 0.04 & 0.04 & $\mathbf{0 . 0 3}$ & 0.04 & (0.03 & 0.03 & 0.04 & 0.016 & 0.018 \\
\hline
\end{tabular}

\section{B) DISCUSSION}

The favorable effects of silicon on berry setting yield and berries quality seem to originate from its positive action on enhancing the tolerance of plants to biotic and abiotic stresses and drought tolerance. This is attributed to its essential role in maintaining plant water balance, photosynthetic activity, erecting the structure of xylem vessels. Previous studies explained these benefits to the formation of silica cuticle double layers formed on leaf epidermal tissue. Silicon also is responsible for water transport and root development as well as increasing the tolerance of plants to producing mildew. The mechanical strength provided by

Fayoum J. Agric. Res. \& Dev., Vol. 31, No.2, July, 2017 
Ahmed, M.M.A. Akl; ; et al.,

silicon to the plant tissues increases their resistance to diseases and insects and in responsible for reducing eth adverse effects of heavy metal toxicity (Lux $\boldsymbol{e t} \boldsymbol{a l}$., 2003; Rodrigues et al., 2003; Ma, 2004 ; and Tahir et al., 2006).

The promoting effect of silicon on fruiting of Superior grapevines was emphasized by the results of Abd El-Hameed (2012); Al-Wasfy (2014); ElKhawaga (2014); Wassel et al (2015); Nagy-Dina (2016); Akl et al (2016), Farahat, (2017) and Youssef, (2017).

The beneficial effects of selenium on fruiting of Superior grapevines might be attributed to its positive action on enhancing the tolerance of the trees to biotic and abiotic stresses and the biosynthesis of carbohydrates and proteins. It is effective in reducing reactive oxygen species (ROS) since it considered as an important antioxidant protects the plant cells from death. Thereby, it is responsible for producing healthy trees able to produce more fruits (NowakBarbara, 2008 and Jakovljevic et al., 2011). These results are in harmony with those obtained by Ibrahiem and Al-Wasfy (2014); Gad El-Kareem et al (2014) and Uwakiem (2015).

\section{CONCLUSION}

Carrying out three sprays of a mixture of potassium silicate at $0.25 \%$ and selenium at $100 \mathrm{ppm}$ gave the best results with regard to yield and berries quality of Superior grapevines grown under sandy soil.

\section{REFERENCES}

Abd El-Hameed, H.M. (2012): Using silicon, boron and folic acid to promote yield quantitatively and qualitatively of Early Superior grapevines. Minia J, of Agric. Res.\& Develop. Vol. (32) No. 5: 869-886.

Akl A.M.; Mohamed, M.A.; El- Sayed, M.A. and Moustafa, M.M.H. ( 2016 ). Behaviour of Superior grapevines to spraying silicon. J. Biol. Chem. Environ. Sc. 11(3): 403- 412.

Al-Wasfy, M.M. (2014): The synergistic effects of using silicon with some vitamins on growth and fruiting of Flame seedless grapevines. Stem Cell 5(1): 8-13.

Association of Official Agricultural Chemists ( 2000 ). Official Methods of Analysis of A.O.A.C. international $17^{\text {th }}$ ed. Published by O.A.C. international U.S.A.

Black, C.A. (1965): Methods of Soil Analysis. Amer. Soc. of Agron., Madison, Wisconsin, U.S.A. pp $1-20$.

El-Khawaga, A.S. (2014): Impact of vitamins B and C, glutamic acid and silicon on fruiting of Superior grapevines. World Rural Observations . 6(4): $57-62$.

Fayoum J. Agric. Res. \& Dev., Vol. 31, No.2, July, 2017 
EFFECT OF SPRAYING SILICON AND SELENIUM ON GROWTH,...... 151

Farahat, I.A.M. ( 2017 ). Studies on pruning and fertilization of early and sweet grapevines growing under Minia Region condition. Ph.D. Thesis Fac. of Agric. Minia Univ., Egypt.

Gad El-Kareem, M.R.; Abdelaal, A.M.K. and Mohamed A.Y. (2014): The synergistic effect of using silicon and selenium on fruiting of Zaghloul date palm (Phoenix dectylifera L.) World Academy of Sci. Engineering and Technology, Inter. J. of Agric. Biosystems Sci. and Engineering 8(3):959-964.

Jakovljevic, M.; Licina, V.; Antic- Mladenov, S. and Velickovic, M. (2011): The effects of selenium application on replant soil and its content in apple leaves and fruits. Acta Hort. 477: IV Inter. Sym. On Replant Proplems P.1.

Ibrahiem, H.I.M. and Al- Wasfy, M.M. (2014): The promotive impact of using silicon and selenium with potassium and boron on fruiting of Valencia orange trees grown under Minia region conditions. World Rural Observations 6(2):28-36.

Lux, A.; Luxova, M.; Abe, J. Tanmoto, E. and Inanaga, S. (2003): The dynamic of silicon deposition in the sorghum root endodermis. New Physiol. 158:437-441.

Ma, J.F. (2004): Role of silicon in enhancing the resistance of plants to biotic and abiotic stresses. Soil Sci. Plant Nutr. 50:11-J8.

Melo, S.P.; Kordnarfer, G.H.; Korndarfer, C.M.; Lana, R.M.G. and Santaon, D.G. (2003): Silicon accumulation and water deficient tolerance in grasses. Scientia Agricola 60:755-759.

Mead, R.; Currow, R.N. and Harted, A.M. (1993): Statistical Methods in Agricultural and Experimental Biology. Second Ed. Chapman \& Hall. London, pp. 10- 44.

Nagy-Dina, A.M. (2016): Response of Flame seedless grapevines to spraying silicon. M. Sc. Thesis Fac. of Agric. Minia Univ. Egypt.

Nowak- Barbara, H. (2008): Effect of selenium on selected macronutrients in maize plants. J. Elemental. 13 (4): $513-519$.

Piper, C.S. (1950): Soil and Plant Analysis, Inter Science New- York pp. 48-110.

Rodrigues, F.A.; Vale, F.X.R.; Kerridorfar, G.H.; Prabhu, A.S.; Datnoff, L.E.; Oliveria, A.M.A. and Zambalim, L. (2003): Influence of silicon on Shealth blight of rice in Brazil. Crop. Prot; 22: 23-29.

Seppanen, M.; Turakainen, M. amd Harikainen, H. (2003): Selenium effects on oxidative stress in Potato. Plant Science. 165: 311-319.

Fayoum J. Agric. Res. \& Dev., Vol. 31, No.2, July, 2017 
Ahmed, M.M.A. Akl ; et al.,

Tahir, M.A.; Rahmatullah, A.; aziz, T.; Ashraf, M.; Kanwal, S. and Magsood, A. (2006): Beneficial effects of silicon in wheat (Triticum aestiviun E.) under salinity stress. Pak. J.Bot.38(5):1715-1727.

Uwakiem, M. Kh., (2015). Effect of spraying silicon, selenium and humic acid on fruiting of Early sweet grapevines. The $2^{\text {nd }}$ Inter. Conf. on Hort. Crops. 15-18 March. Egypt. J. Hort. 42(1): pp:333-343.

Wassel, A.M.M.; Gobara, A.A.; Mohamed, A.Y. and El- Sadek, M.A. (2015): Response of Ewaise mango trees to foliar application of boron and silicon . J. Biol. Chem. Environ. Sci. 10(4): 423-437.

Youssef, M.S.M. (2017): Effect of spraying silicon on fruiting of Sakkoti date palms. M.Sc. Thesis Fac. of Agric. Minia Univ. Egypt.

$$
\begin{aligned}
& \text { تأثير رش السيليكون والسيلينيوم علي النمو الخضرى العربي الحالة الغذائية للكرمة وعقد الحبات وكمية }
\end{aligned}
$$

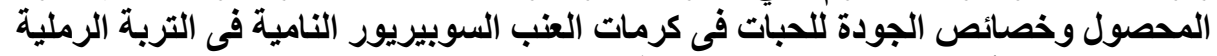

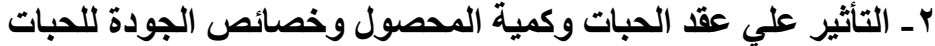

$$
\begin{aligned}
& \text { أحمد محمد محمد أبو زيد عقل*، فيصل فاضل أحمد*، محمد علي مجاور عبادة ***، سامتح السيد مسعود } \\
& \text { ** يس }
\end{aligned}
$$

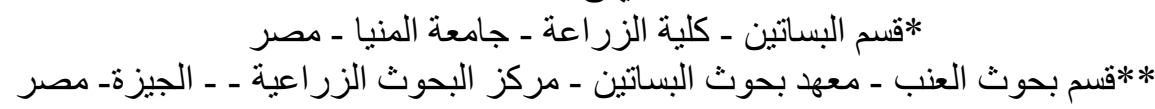

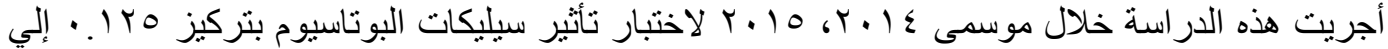

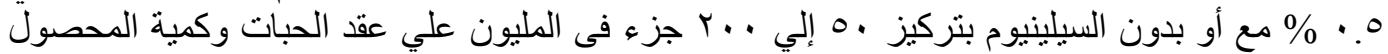

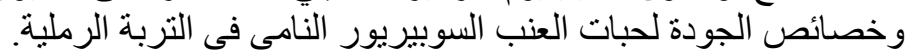

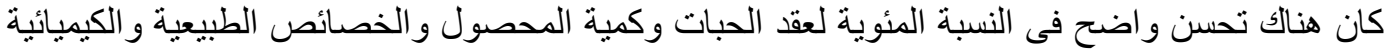

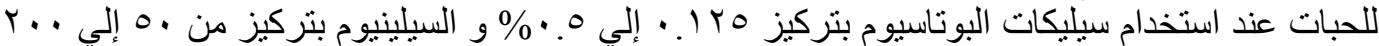

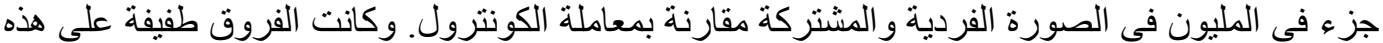

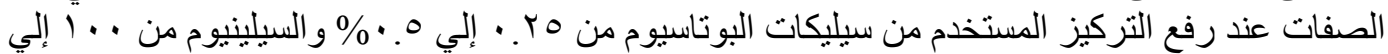

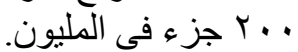

$$
\begin{aligned}
& \text { أمكن الحصول علي أفضل النتائج بخصوص عقد الحبات وكمية المحصول وخصائص الجودة للحبات }
\end{aligned}
$$

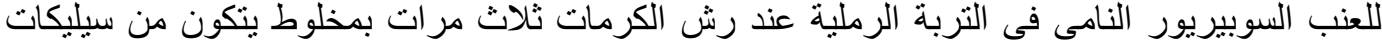

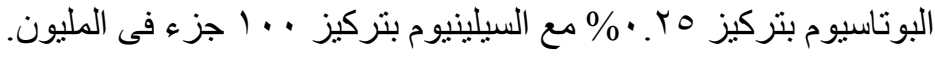

Fayoum J. Agric. Res. \& Dev., Vol. 31, No.2, July, 2017 